\title{
Pengaruh Leverage, Opini Audit Tahun Sebelumnya, Pertumbuhan Perusahaan, dan Ukuran Perusahaan terhadap Opini Audit Going Concern
}

\author{
Kusuma Indawati Halim \\ Universitas Widya Dharma Pontianak, Kalimantan Barat \\ kusumaindawati@gmail.com
}

*Corresponding Author

Submitted: December 25, 2020

Accepted: January 18, 2021

Published: February 2, 2021

\begin{abstract}
Audit reports are used by auditors to inform the accuracy of the information in the financial statements. The auditor as an independent party has the competence to provide an opinion on the client's financial condition. If it is estimated that the company cannot continue its activities, it is likely that it will get a going concern audit opinion. Audit opinion can help investors and other stakeholders in assessing the status of the company's business continuity. The important thing from a going concern audit opinion is to provide additional information for investors in making investment decisions. The purpose of this study is to examine the relationship between leverage, prior audit opinion, company growth and company size with going concern audit opinion on manufacturing companies listed on the Indonesia Stock Exchange. The study used a sample of 125 companies for the 2014-2018 period. The results of data analysis were obtained from logistic regression tests. The empirical results show that prior opinion and leverage increase the likelihood of receiving a going concern opinion. Meanwhile, company growth and company size have no effect on going concern audit opinion. Nagelkerke's $R$ Square test shows the ability of the factors in this study to explain $63.1 \%$ of going-concern audit opinion, while $36.9 \%$ is explained by other factors outside the research model. The findings of this study are expected to help investors and other stakeholders to consider the company's prospects before making investment decisions.
\end{abstract}

Keywords: Leverage; Prior Opinion; Company Growth; Company Size; Going Concern Audit Opinion

\section{PENDAHULUAN}

Kegiatan produksi dari perusahaan manufaktur ditujukan untuk memenuhi berbagai kebutuhan masyarakat. Dalam upaya mencapai tujuannya, perusahaan harus mampu mengkoordinasikan semua sumber daya yang dimiliki agar dapat mempertahankan kelangsungan usahanya (going concern). Asumsi ini mensyaratkan bahwa perusahaan memiliki kemampuan untuk menjaga kelangsungan bisnis (Hapsoro dan Suryanto, 2017). Kemampuan perusahaan dalam menjalankan aktivitasnya dapat dinilai dari informasi keuangan. Perusahaan go public dituntut menyajikan hasil audit laporan keuangan kepada pihak investor, kreditur, karyawan, pemerintah dan masyarakat. Laporan keuangan adalah alat bagi perusahaan untuk mengkomunikasikan hasil kinerja perusahaan kepada pihak yang berkepentingan.

Pada saat investor berniat untuk berinvestasi pada satu perusahaan, maka yang perlu dipelajari terlebih dahulu adalah kondisi financial perusahaan, terutama mengenai keberlangsungan usahanya (going concern). Opini audit atas laporan keuangan adalah pengetahuan dasar yang mesti diketahui oleh investor. Akuntan publik dianggap sebagai pihak yang berkompeten dalam memberikan opini audit terhadap laporan keuangan. Laporan keuangan yang telah diaudit dinilai lebih mencerminkan kenyataan, akurat, lengkap dan netral (Robu et al., 2015). Opini audit dari 
akuntan publik lebih terjamin kualitas informasinya sehingga dapat dijadikan sebagai dasar bagi investor guna mengambil keputusan investasinya.

Perusahaan yang memiliki porsi utang yang relatif tinggi dapat mengakibatkan keterbatasan keuangan (Ilyukhin, 2015). Rasio utang perusahaan terhadap total aset sebagai ukuran leverage keuangan dapat digunakan untuk mengevaluasi kinerja manajemen. Tingginya rasio leverage dapat menimbulkan spekulasi negatif dari investor dan lembaga keuangan mengenai upaya perusahaan untuk mempertahankan kelangsungan usahanya. Situasi ini terjadi karena perolehan dana akan lebih difokuskan untuk menutupi biaya bunga pinjaman dibandingkan aktivitas operasional usaha perusahaan. Kepemilikan tingkat utang yang lebih tinggi dibanding perolehan laba akan menyebabkan perusahaan menghadapi risiko kebangkrutan (Aryantika dan Rasmini, 2015).

Opini audit going concern tahun sebelumnya yang diperoleh perusahaan, diprediksi menjadi faktor perusahaan dalam memperoleh pinjaman dari lembaga keuangan dan investasi dari investor pihak luar. Opini audit going concern membuat investor akan berpikir ulang untuk menginvestasikan uangnya. Apabila perusahaan tidak melakukan tindakan perbaikan terhadap kesulitan yang dihadapi, maka auditor dapat mempertimbangkan kembali mengeluarkan opini yang sama tahun berikutnya (Utami et al., 2017).

Pertumbuhan perusahaan yang baik dapat dinilai dari peningkatan penjualan setiap tahun (Srimindarti et al., 2019). Penjualan yang semakin meningkat menunjukkan perusahaan mampu beroperasi secara normal tanpa ada kendala masalah. Peningkatan penjualan akan mendukung perolehan laba perusahaan (Lazăr, 2016). Dapat diartikan bahwa adanya peningkatan kinerja perusahaan setiap tahun menandakan bahwa perusahaan tersebut memiliki pendapatan yang relatif stabil disetiap tahunnya, sehingga dapat dikatakan bahwa, perusahaan tersebut dapat menjamin akan kelangsungan usahanya.

Perusahaan yang berukuran besar cenderung memiliki sistem pengendalian intern yang memadai sehingga mampu menghadapi persaingan bisnis (Madhani, 2016). Perusahaan besar dinilai lebih mampu menyelesaikan masalah keuangan dibanding perusahaan kecil. Laporan keuangan tahunan dari perusahaan besar cenderung disoroti para investor sehingga mendorong manajemen untuk berhati-hati dalam pengambilan keputusan. Perusahaan dengan ukuran lebih besar memiliki kepastian dalam mempertahankan kinerjanya sehingga mengurangi ketidakpastian mengenai kelangsungan hidupnya (Kurnia dan Cellica, 2016).

Opini audit menjadi petunjuk awal mengenai kondisi keuangan perusahaan dan berpengaruh terhadap keputusan yang diambil oleh investor, kreditur, maupun manajemen. Jika perusahaan memperoleh opini audit going concern, maka investor akan mempertimbangkan kembali investasi yang sudah direncanakan. Demikian halnya dengan kreditur akan memikirkan kembali pinjaman yang diberikan kepada perusahaan. Manajemen perusahaan juga akan mengambil tindakan yang tepat agar dapat mempertahankan kelangsungan usahanya.

Standar Profesional Akuntan Publik (SPAP) dalam Standar Auditing (SA) 570 menjelaskan bahwa faktor-faktor penilaian atas kemampuan manajemen mempertahankan kelangsungan usahanya meliputi ketidakpastian yang berkaitan dengan hasil suatu peristiwa, ukuran dan kompleksitas entitas, sifat dan kondisi bisnis, serta tingkat keterpengaruhannya oleh faktor eksternal.Topik ini dipilih mengingat pentingnya pemahaman akan dampak dari dikeluarkannya opini audit bagi perusahaan, sehingga akuntan publik perlu berhati-hati sebelum membuat keputusan opini audit going concern. Akuntan publik perlu memahami secara cermat tentang standar yang mengatur keputusan opini going concern sehingga hasil audit laporan keuangan benarbenar mencerminkan kondisi sebenarnya. Perusahaan manufaktur diwajibkan Otoritas Jasa Keuangan untuk menyampaikan hasil audit laporan keuangan kepada publik. Audit atas laporan keuangan perusahaan manufaktur ditujukan untuk menilai kewajaran penyajian laporan keuangan. Banyaknya transaksi yang harus diaudit menuntut ketelitian dan integritas yang tinggi dari akuntan publik. Berdasarkan data di Bursa Efek Indonesia diketahui masih terdapat beberapa perusahaan yang menerima opini audit going concern.

Tabel 1. Penerimaan Opini Audit

Tahun Opini Audit




\begin{tabular}{ccc}
\cline { 2 - 3 } & $\begin{array}{c}\text { Going } \\
\text { Concern }\end{array}$ & $\begin{array}{c}\text { Non Going } \\
\text { Concern }\end{array}$ \\
\hline 2014 & 9 & 116 \\
2015 & 10 & 115 \\
2016 & 9 & 116 \\
2017 & 8 & 117 \\
2018 & 9 & 116 \\
\hline Sumber: Hasil Pengolahan (2020)
\end{tabular}

Jumlah perusahaan yang paling banyak menerima opini audit going concern terjadi pada tahun 2015 sebanyak 10 perusahaan, sedangkan yang menerima opini audit non going concern paling banyak terjadi pada tahun 2017 sebanyak 117 perusahaan. Perusahaan yang menerima opini audit going concern merupakan indikasi bahwa auditor telah menilai bahwa auditee akan menghadapi kesulitan mempertahankan bisnisnya.

Penelitian ini bertujuan untuk menganalisis memperoleh bukti adanya pengaruh leverage, opini audit tahun sebelumnya, pertumbuhan perusahaan dan ukuran perusahaan terhadap kemungkinan diterbitkannya opini audit going concern pada perusahaan manufaktur yang terdaftar di Bursa Efek Indonesia. Informasi going concern bisa bermanfaat untuk mengambil keputusan bagi investor untuk memprediksi kondisi keuangan perusahaan yang menjual surat berharga. Informasi ini juga menjadi early warning mengenai kemampuan perusahaan dalam mempertahankan kelangsungan usahanya.

\section{Teori Agensi}

\section{STUDI LITERATUR}

Teori agensi memaparkan relasi antara agent (manajemen) dan principal (pemegang saham). Agent ditunjuk oleh principal untuk menjalankan transaksi bisnis tertentu dan diharapkan dapat mendukung kepentingan principal. Tetapi seiring dengan berjalannya aktivitas bisnis, timbul ketidakpercayaan antara kedua pihak yang mengakibatkan berbagai masalah dalam perusahaan. Kepentingan yang tidak sejalan menyebabkan ketidakefisienan dan kerugian finansial. Posisi manajemen sebagai agent memikul tanggung jawab terhadap kelangsungan usaha perusahaan. Masalah keagenan terjadi jika timbul konflik antara agent dan principal dimana saat menjalankan kewajibannya, manajemen dapat mempertimbangkan untuk memenuhi kepentingan sendiri dengan mengorbankan kepentingan pemilik (Muhanguzi, 2019).

Pihak principal akan menunjuk auditor untuk mengevaluasi kinerja manajemen yang didasarkan atas laporan keuangan akhir tahun. Auditor akan menilai kewajaran informasi yang tersaji pada laporan keuangan. Selain dari penilaian wajar atau tidaknya laporan keuangan, auditor akan menilai jalannya kelangsungan usaha. Jika dinilai tidak mampu mempertahankan usahanya, maka auditor akan menerbitkan laporan audit dengan opini audit going concern (Andrian et al., 2019).

\section{Leverage dan Opini Audit Going Concern}

Tingginya rasio debt to asset dapat menjadi petunjuk bahwa perusahaan berada pada posisi kesulitan keuangan. Perolehan dana lebih ditujukan untuk membiayai utang, sedangkan untuk kegiatan usaha akan semakin berkurang. Bukti dari penelitian sebelumnya yang dilakukan oleh Aryantika dan Rasmini (2016) serta Simamora dan Hendarjatno (2019) menunjukkan perusahaan dengan rasio debt to asset yang tinggi akan memperbesar kemungkinan memperoleh opini audit going concern. Perusahaan akan berada dalam kondisi sulit karena menanggung beban bunga yang tinggi. Keadaan ini mengakibatkan kinerja perusahaan dinilai buruk sehingga berisiko terhadap kelangsungan usaha.

$\mathrm{H}_{1}$ : Leverage berpengaruh terhadap Opini Audit Going Concern

\section{Opini Audit Tahun sebelumnya dan Opini Audit Going Concern}

Situasi penyebab perusahaan menerima opini audit going concern tahun sebelumnya seperti menurunnya harga saham, kesulitan memperoleh pinjaman, dan keraguan dari stakeholder terhadap kinerja perusahaan. Temuan dari hasil penelitian dari Krissindiastuti dan Rasmini (2016) 
serta Aryantika dan Rasmini (2016) juga memperlihatkan jika perusahaan tidak mengalami peningkatkan kondisi keuangan kearah yang lebih baik maka besar kemungkinan akan memperoleh kembali opini audit going concern. Sedangkan hasil penelitian Sandi, et al (2014) menyatakan opini audit going concern tahun sebelumnya yang diterima auditee menunjukkan perusahaan dalam kondisi kesulitan keuangan dan berpeluang untuk memperoleh opini audit going concern kembali pada periode selanjutnya

$\mathrm{H}_{2}$ : Opini Audit Tahun sebelumnya berpengaruh terhadap Opini Audit Going Concern

\section{Pertumbuhan Perusahaan dan Opini Audit Going Concern}

Keyakinan untuk tetap menjaga posisi keuangan akan mendukung perusahaan tetap terus tumbuh dan berkembang. Semakin tinggi pertumbuhan penjualan, maka semakin kecil kemungkinan auditor untuk memberikan opini going concern. Dalam kondisi ini, kemungkinan perusahaan menghadapi kebangkrutan sangat kecil. Penelitian yang dihasilkan oleh Wardayanti (2017) dan Srimindarti et al., (2019) menyatakan adanya hubungan negatif antara pertumbuhan perusahaan dengan opini audit going concern. Sebaliknya hasil penelitian Purba dan Nazir (2018) menyatakan pertumbuhan memiliki hubungan positif terhadap opini audit going concern. Meningkatnya volume penjualan akan memberi mendukung perusahaan untuk mempertahankan keberlangsungan hidupnya serta meningkatkan volume pertumbuhannya

$\mathrm{H}_{3}$ : Pertumbuhan Perusahaan berpengaruh terhadap Opini Audit Going Concern

\section{Ukuran Perusahaan dan Opini Audit Going Concern}

Efektivitas penggunaan aktiva akan mendukung kelancaran jalannya perusahaan. Semakin banyak aktiva yang dimiliki akan mendorong kenaikan produksi sehingga berdampak pada kenaikan penjualan. Perusahaan yang dapat memanfaatkan aktiva secara optimal akan terus mengembangkan usahanya sehingga dapat bertahan menghadapi persaingan. Kelangsungan operasi perusahaan akan terjamin sehingga kemungkinan menerima opini audit going concern semakin kecil. Pernyataan ini selaras dengan hasil penelitian terdahulu yang dihasilkan oleh Rakatenda dan Putra (2016) dan Suryani (2020), akan tetapi berbeda dengan hasil penelitian Akbar dan Ridwan (2019) yang menemukan ukuran perusahaan memiliki pengaruh positif terhadap opini audit going concern. Perusahaan besar memiliki manajemen yang efisien sehingga mampu mempertahankan kelangsungan usahanya.

$\mathrm{H}_{4}$ : Ukuran Perusahaan berpengaruh terhadap Opini Audit Going Concern

\section{Opini Audit Going Concern}

Jika laporan keuangan telah melalui proses auditing, maka lebih diyakini kewajaran informasinya oleh para pengguna. Opini yang diberikan auditor menjadi petunjuk penting bagi investor untuk mengambil keputusan berinvestasi. Dalam pelaksanaan pekerjaan audit, auditor tidak hanya dituntut untuk memperhatikan angka-angka yang tersaji pada laporan keuangan, tetapi juga menilai eksistensi kelangsungan usaha atau kelancaran perusahaan menjalankan aktivitasnya pada periode mendatang. Penerimaan opini going concern menjadi petunjuk perusahaan berada pada posisi kesulitan keuangan dan kemungkinan mengalami kebangkrutan. Opini audit going concern dapat diukur dengan variabel dummy (Andrian et al., 2019), yaitu:

Kode 1: Opini audit going concern.

Kode 0: Opini audit non going concern.

\section{Leverage}

Agar dapat mempertahankan aktivitas ekonomi, perusahaan membutuhkan pendanaan yang diperoleh dari kreditur berupa pinjaman jangka panjang. Pendanaan ini digunakan untuk mendukung kegiatan yang dijalankan perusahaan. Leverage digunakan untuk mengukur beban utang yang harus ditanggung dengan aset yang dimiliki perusahaan. Leverage diproksikan dengan rasio debt to asset (Kasmir, 2018). Apabila nilai debt to asset ratio tinggi, maka mengindikasikan perusahaan lebih banyak mendanai operasionalnya dengan utang daripada aset yang dimiliki. 


$$
\text { Debt to asset ratio }=\frac{\text { Total Debt }}{\text { Total assets }}
$$

\section{Opini Audit Tahun Sebelumnya}

Berjalannya aktivitas ekonomi pada tahun tertentu tidak terlepas dari kondisi tahun sebelumnya. Jika sudah memperoleh opini audit going concern pada periode sebelumnya, maka pada tahun berjalan perusahaan harus lebih berhati-hati agar tidak kembali menerima opini yang sama (Utami dan Astika, 2017). Hal ini terjadi jika dinilai oleh auditor belum ada tindakan dari manajemen untuk perbaikan kinerja. Opini audit tahun sebelumnya diukur dengan variabel dummy (Andrian et al., 2019), yaitu:

Kode 1: Opini audit going concern tahun sebelumnya.

Kode 0: Opini audit non going concern tahun sebelumnya.

\section{Pertumbuhan Perusahaan}

Kekuatan perusahaan untuk menghadapi risiko bisnis dapat ditentukan dari pertumbuhan perusahaan. Perusahaan tentu sudah memiliki strategi untuk mengantisipasi risiko-risiko yang mungkin terjadi. Pertumbuhan perusahaan digambarkan dari volume penjualan yang merupakan aktivitas pokok perusahaan. Penjualan perusahaan yang selalu meningkat akan turut meningkatkan laba. Peningkatan laba mendukung dalam mendanai keberlangsungan jalannya perusahaan seperti membiayai operasi dan melunasi kewajiban. Pertumbuhan perusahaan dapat diproksikan dengan pertumbuhan penjualan (Srimindarti et al., 2019):

$$
\text { Pertumbuhan Penjualan }=\frac{\text { Penjualan bersih }{ }_{t}-\text { Penjualan bersih }_{t-1}}{\text { Penjualan bersih }}
$$

\section{Ukuran Perusahaan}

Ukuran perusahaan dikelompokkan menjadi perusahaan dengan ukuran besar, menengah, dan kecil. Besar kecilnya perusahaan diukur dengan total aset, nilai pasar saham dan lainnya. Perusahaan yang lebih kecil dinilai tidak memiliki kemampuan untuk bersaing dengan perusahaan besar terutama dalam mempertahankan kinerja. Perusahaan besar memiliki kesempatan memperoleh pinjaman dari pihak luar untuk memperoleh kredit dari Investor karena dinilai memiliki kinerja yang baik dengan peluang kebangkrutan yang rendah. Skala perusahaan diproksikan dengan logaritma natural total aset (Abbasi dan Malik. 2015).

Ukuran Perusahaan $=$ LN (Total aset)

\section{Populasi Dan Sampel}

\section{METODE}

Penelitian ini menggunakan populasi dari perusahaan manufaktur di Bursa Efek Indonesia dari periode 2014-2018 dengan jumlah sebanyak 165 perusahaan. Seleksi sampel menggunakan purposive sampling. Kriteria sampel yaitu perusahaan yang tidak di-delisting ataupun di-suspend selama periode penelitian dan melaporkan Initial Public Offering (IPO) sebelum tahun 2014.

Dari hasil seleksi, diperoleh data perusahaan yang mengalami delisting dan suspend sebanyak 6 perusahaan, yang belum IPO sebanyak 34 perusahaan, sehingga terkumpul sampel sebanyak 125 perusahaan. Total data penelitian berjumlah 625 data diperoleh dari 125 perusahaan dikalikan dengan lima tahun penelitian.

\section{Metode Analisis Data}

Tahapan pengujian data penelitian dimulai dari analisis statistik deskriptif, yaitu untuk menganalisis data dengan cara mendeskripsikan atau menggambarkan data yang terkumpul sebagaimana adanya meliputi nilai rata-rata, nilai minimum, nilai maksimum, dan standar deviasi. Tahap kedua adalah uji multikolinearitas yaitu untuk mengetahui apakah pada model regresi ditemukan adanya korelasi antarvariabel independen. Cara mendeteksi ada tidaknya 
multikolinearitas dengan melihat nilai variance inflation factor (VIF) dan tolerance. Apabila nilai VIF $<10$, dan tolerance $>0,1$, maka tidak terjadi masalah multikolinearitas. Tahap ketiga adalah uji kelayakan model (Goodness of Fit) dengan kriteria jika nilai Hosmer and Lemeshow Goodnessof-fit test statistic sama dengan atau kurang dari 0,05, berarti ada perbedaan signifikan antara model dengan nilai observasinya, sebaliknya jika nilai Hosmer and Lemeshow Goodness-of-fit test statistic lebih besar dari 0,05 , berarti model mampu memprediksi nilai observasinya atau dapat dikatakan model dapat diterima karena cocok dengan data observasi (Ghozali, 2016).

Tahap keempat adalah uji Overall Fit Model, yaitu dengan menggunakan nilai -2logL. Jika terjadi adanya pengurangan nilai antara $-2 \operatorname{LogL}$ awal dengan nilai $-2 \mathrm{LogL}$ akhir, berarti model yang dihipotesiskan fit dengan data. Tahap kelima adalah analisis koefisien determinasi yang dapat dilihat pada nilai Nagelkerke $R$ Square yang bervariasi antara 0 (nol) sampai 1 (satu). Semakin mendekati nilai 1 maka model dianggap semakin goodness of fit, sementara semakin mendekati 0 maka model dianggap semakin tidak goodness of fit. Tahap keenam adalah dengan matriks klasifikasi, yaitu menilai estimasi yang benar dan salah serta hasil penelitian yang ada dinyatakan dalam bentuk presentase. Tahap terakhir adalah dengan analisis regresi logistic dengan menggunakan persamaan regresi berikut:

Keterangan:

$$
\operatorname{Ln} \frac{\mathrm{OAGC}}{1-\mathrm{OAGC}}=\beta_{0}+\beta_{1} \mathrm{X}_{1}+\beta_{2} \mathrm{X}_{2}+\beta_{3} \mathrm{X}_{3}+\beta_{4} \mathrm{X}_{4}+\square
$$

Ln $\frac{\text { OAGC }}{1-\mathrm{OAGC}}=$ probabilitas menerima opini audit going concern

$\beta 0=$ koefisien regresi konstanta

$\beta(1,2,3)=$ koefisien regresi masing-masing variabel independen

$\mathrm{X}_{1} \quad=$ variabel independen, opini audit tahun sebelumnya

$\mathrm{X}_{2} \quad=$ variabel independen, pertumbuhan perusahaan

$\mathrm{X}_{3} \quad=$ variabel independen, ukuran perusahaan

$\mathrm{X}_{4} \quad=$ variabel independen, leverage

$\varepsilon \quad=$ error

Analisis Statistik Deskriptif

HASIL

Tabel 1 mendeskripsikan variabel penelitian yang terangkum dari 625 data penelitian.

Tabel 2. Statistik Deskriptif

\begin{tabular}{lrrrrr}
\hline & $\mathrm{N}$ & Minimum & Maximum & Mean & Std. Deviation \\
\hline Leverage & 625 &, 0662 & 5,0733 &, 568897 &, 5342590 \\
PertumbuhanPerusahaan & 625 &,- 9868 & 14,2311 &, 089158 &, 6723878 \\
UkuranPerusahaan & 625 & 25,2156 & 33,4737 & 28,520737 & 1,5723058 \\
Valid N (listwise) & 625 & & & & \\
\hline
\end{tabular}

Sumber: Hasil Pengolahan (2020)

Hasil analisis statistik deskriptif menunjukkan variabel leverage memiliki nilai minimum sebesar 0,0662, di mana nilai ini dimiliki oleh PT Industri Jamu dan Farmasi Sido Muncul Tbk pada tahun 2014 dengan nilai total aset sebesar Rp2.821.399.000.000,00 dan total utang sebesar Rp186.740.000.000. Nilai maksimum dari leverage adalah sebesar 5,0733, di mana nilai tersebut dimiliki oleh PT Asia Pacific Fibers Tbk pada tahun 2017 dengan nilai total aset sebesar Rp3.137.269.106.340,00 dan total utang sebesar Rp15.916.297.794.996,00. Variabel leverage juga memiliki nilai rata-rata sebesar 0,568897 dan nilai standar deviasi yang sebesar 0,5342590.

Berikutnya variabel pertumbuhan perusahaan memiliki nilai minimum sebesar $-0,9868$ oleh PT Jakarta Kyoei Steel Works Tbk pada tahun 2018 dengan aktivitas penjualan perusahaan pada tahun 2017 sebesar Rp11.819.781.048,00 sedangkan pada tahun 2018 penjualan menurun menjadi Rp156.504.840,00. Nilai maksimum dari pertumbuhan perusahaan sebesar 14,2311 oleh PT Bumi Teknokultura Unggul Tbk pada tahun 2016 dengan penjualan sebesar Rp748.088.902.523,00 dan penjualan yang terjadi di tahun sebelumnya sebesar Rp49.116.023.376,00. Variabel pertumbuhan 
perusahaan memiliki nilai rata-rata sebesar 0,089158 dan nilai standar deviasi yang sebesar 0,6723878 .

Terakhir adalah variabel ukuran perusahaan memiliki nilai minimum sebesar 25,2156, di mana nilai ini dimiliki oleh PT Primarindo Asia Infrastructure Tbk pada tahun 2017 dengan nilai total aset sebesar Rp89.327.328.853,00. Nilai maksimum dari ukuran perusahaan adalah sebesar 33,4737, di mana nilai tersebut dimiliki oleh PT Astra International Tbk pada tahun 2018 dengan nilai total aset sebesar Rp344.711.000.000.000,00. Variabel ukuran perusahaan juga memiliki nilai rata-rata sebesar 28,520737 dan nilai standar deviasi yang sebesar 1,5723058

\section{Analisis Regresi Logistik}

Hasil uji regresi logistik dapat ditentukan pada nilai variables in the equation yaitu nilai signifikansi dibandingkan dengan alpha 0,05. Jika nilai signifikansi $<0,05$, maka hipotesis diterima dan sebaliknya.

\begin{tabular}{lrr} 
Tabel 3. Uji Regresi Logistik \\
Variables in the Equation & & \\
\hline & \multicolumn{1}{c}{ B } & Sig. \\
\cline { 2 - 3 } Leverage &, 680 &, 004 \\
Opini Audit Tahun sebelumnya & 5,131 &, 000 \\
Pertumbuhan Perusahaan &,- 267 &, 336 \\
Ukuran Perusahaan &,- 197 &, 301 \\
Constant & 1,184 &, 825 \\
\hline
\end{tabular}

Sumber: Hasil Pengolahan (2020)

\section{Leverage dan Opini Audit Going Concern}

\section{PEMBAHASAN}

Hasil uji hipotesis pertama memperlihatkan bukti bahwa penerbitan opini audit going concern oleh auditor akan mempertimbangkan rasio leverage. Perusahaan dengan beban utang yang cenderung tinggi akan menanggung beban bunga sehingga menyebabkan perolehan laba menurun. Apabila perusahaan tidak mampu risiko keuangan ini, maka dapat mengancam kelangsungan hidup perusahaan. Penelitian ini sejalan dengan penelitian yang dihasilkan Aryantika dan Rasmini (2016) serta Simamora dan Hendarjatno (2019) yang juga menemukan leverage berpengaruh positif terhadap penerimaan opini audit going concern. Namun penelitian ini tidak sejalan dengan hasil penelitian Yuliyani dan Erawati (2017) serta Kemuning dan Juliarsa (2016) yang menemukan leverage tidak berpengaruh terhadap opini audit. Hasil penelitian menunjukkan rasio leverage menjadi salah satu faktor yang dipertimbangkan akuntan publik untuk memberikan opini audit going concern. Perusahaan harus lebih berhati-hati dalam menggunakan pendanaan untuk memenuhi kewajiban karena kondisi ini akan berdampak pada menurunnya laba sehingga dapat menghambat jalannya usaha.

\section{Opini Audit Tahun sebelumnya dan Opini Audit Going Concern}

Hasil uji hipotesis kedua memberikan bukti bahwa auditor dalam menerbitkan opini audit going concern akan turut memperhatikan opini audit periode lalu. Pemberian opini audit going concern pada periode lalu turut menimbulkan hilangnya kepercayaan publik terhadap perusahaan. Jika tidak segera dilakukan tindakan perbaikan terhadap kinerja perusahaan maka dapat dipastikan perusahaan akan menerima opini audit going concern pada tahun berjalan. Penelitian ini sejalan dengan penelitian yang dilakukan oleh Krissindiastuti dan Rasmini (2016) dan Aryantika dan Rasmini (2016) yang menyatakan bahwa opini audit periode lalu berpengaruh positif terhadap penerimaan opini audit going concern. Akan tetapi, hasil penelitian ini tidak sesuai dengan penelitian Kurnia dan Cellica (2016) yang menemukan opini audit tahun sebelumnya berpengaruh negatif terhadap opini audit going concern. Hasil temuan ini membuktikan akuntan publik akan memperhatikan opini audit tahun sebelumnya untuk dijadikan petunjuk dalam mengevaluasi tindakan perbaikan dari manajemen pada tahun berjalan.

\section{Pertumbuhan Perusahaan dan Opini Audit Going Concern}


Hasil uji hipotesis ketiga menyatakan pertumbuhan perusahaan tidak memiliki pengaruh terhadap penerimaan opini audit going concern. Perusahaan dengan volume penjualan yang tinggi tetapi tidak diikuti dengan kemampuan untuk mempertahankan kinerjanya sehingga tidak menutup kemungkinan perusahaan kembali memperoleh opini audit going concern. Demikian juga penurunan penjualan tidak menandakan perusahaan berada dalam kondisi kesulitan keuangan. Penelitian ini sesuai dengan hasil penelitian dari dewi et al., (2016) dan Utami et al., (2017) yang juga menemukan kesimpulan yang sama. Namun hasil penelitian ini tidak sejalan dengan hasil penelitian dari Wardayanti (2017) dan Srimindarti et al., (2019) yang menyatakan pertumbuhan perusahaan berpengaruh negatif terhadap opini audit going concern. Hasil penelitian ini menunjukkan perusahaan yang mengalami peningkatan penjualan bersih namun tidak diikuti dengan kemampuan meningkatkan laba atau menanggung beban operasi, maka tidak menutup kemungkinan perusahaan menerima opini audit going concern.

\section{Ukuran Perusahaan dan Opini Audit Going Concern}

Hasil uji hipotesis keempat menyatakan ukuran perusahaan tidak memiliki pengaruh terhadap opini audit going concern. Ukuran perusahaan tidak menentukan manajemen lebih mampu mengendalikan aktivitas perusahaan. Manajemen dengan kinerja yang buruk tentu akan menghambat perkembangan usaha dan dapat berdampak pada ketidakmampuan perusahaan bertahan dalam jangka panjang. Sebaliknya, apabila kinerja manajemen baik, maka akan memperkecil potensi memperoleh opini audit going concern. Penelitian ini selaras dengan hasil penelitian dari Effendi (2019), Chandra et al., (2019) dan Widoretno (2019) yang juga menemukan ukuran perusahaan tidak berpengaruh terhadap opini audit going concern, akan tetapi tidak sesuai dengan hasil penelitian dari Rakatenda dan Putra (2016) dan Suryani (2020) yang menyatakan ukuran perusahaan berpengaruh negatif terhadap opini audit going concern. Hasil penelitian ini menunjukkan bahwa ukuran perusahaan bukan merupakan penilaian dalam pemberian opini audit going concern, karena kelangsungan usaha lebih dihubungkan dengan kemampuan manajemen dalam mengelola keuangan perusahaan.

\section{KESIMPULAN}

Hasil pengujian regresi logistik menemukan bahwa leverage yang diproksikan dengan debt to assets memiliki pengaruh positif terhadap opini audit going concern, opini audit tahun sebelumnya yang diukur dengan variabel dummy memiliki pengaruh positif terhadap opini audit going concern, pertumbuhan perusahaan yang diproksikan dengan pertumbuhan penjualan tidak memiliki pengaruh terhadap opini audit going concern, dan ukuran perusahaan yang diproksikan dengan logaritma natural total aset tidak memiliki pengaruh terhadap opini audit going concern. Penelitian ini memiliki keterbatasan yakni hanya menggunakan sampel dengan kurun waktu lima tahun yaitu tahun 2014 sampai dengan 2018. Berdasarkan keterbatasan ini, peneliti selanjutnya disarankan dapat memperpanjang rentan waktu penelitian. Selain itu, peneliti selanjutnya diharapkan dapat menggunakan perusahaan di bidang usaha lain seperti pertambangan agar lebih menggambarkan situasi akan opini audit going concern. Temuan dari penelitian ini diharapkan dapat membantu stakeholder untuk mempelajari kondisi keuangan perusahaan agar terhindar dari kerugian pada saat mengambil keputusan investasi. Akuntan publik juga harus selalu mempertahankan sikap independensi yang kuat dalam memutuskan pemberian opini agar benarbenar objektif tanpa dipengaruhi oleh pihak lain.

\section{REFERENSI}

Abbasi, A \& Malik, Q. A. (2015). Firms' Size Moderating Financial Performance in Growing Firms: An Empirical Evidence from Pakistan. International Journal of Economics and Financial Issues, 2015, 5(2), 334-339. Retrieved from https://www.econjournals.com/index.php/ijefi/article/view/1074 
Andrian, T., et all. (2019). The Acceptance of Going Concern: Does Audit Opinion Matter?. International Journal of Innovation, Creativity and Change. Volume 9, Issue 10, 1-13, Retrieved from https://www.ijicc.net/images/vol9iss10/91002_Andrian_2019_E_R.pdf

Aryantika, N., \& Rasmini, N. (2015). Profitabilitas, Leverage, Prior Opinion dan Kompetensi Auditor Pada Opini Audit Going Concern. E-Jurnal Akuntansi, 11(2), 414-425. Retrieved from https://ojs.unud.ac.id/index.php/Akuntansi/article/view/11020

Chandra, I., et all. (2019). Pengaruh Kualitas Audit, Debt Default (Kegagalan Hutang) dan Ukuran Perusahaan terhadap Penerimaan Opini Audit Going Concern pada Subsektor Perusahaan Tekstil \& Garment Yang Terdaftar Di Bursa Efek Indonesia pada Periode 20142017. Owner: Riset Dan Jurnal Akuntansi,3(2), 289-300. https://doi.org/10.33395/owner.v3i2.124

Dewi, N., et all. (2016). Prior Opinion Dan Pertumbuhan Perusahaan Sebagai Pemoderasi Pengaruh Model Prediksi Kebangkrutan Altman Pada Pemberian Opini Going Concern. E-Jurnal Ekonomi Dan Bisnis Universitas Udayana, Retrieved from https://ojs.unud.ac.id/index.php/EEB/article/view/20869

Effendi, B. (2019). Kualitas Audit, Kondisi Keuangan, Ukuran Perusahaan dan Penerimaan Opini Audit Going Concern. Owner: Riset Dan Jurnal Akuntansi,3(1), 9-15. https://doi.org/10.33395/owner.v3i1.80

Ghozali, I. (2016). Aplikasi Analisis Multivariete dengan Program (IBM SPSS). Semarang: Badan Penerbit Universitas Diponegoro.

Hapsoro, D., \& Suryanto, T. (2017). Consequences of going concern opinion for financial reports of business firms and capital markets with auditor reputation as a moderation variable-an experimental study. European Research Studies Journal, 20, 197-223, DOI: $10.35808 / \mathrm{ersj} / 637$

Ilyukhin, E. (2015). The Impact of Financial Leverage on Firm Performance: Evidence from Russia. Journal of Corporate Finance Research, Vol. 9, No. 2, pp. 24-36, 2015, Available at https://papers.ssrn.com/sol3/papers.cfm?abstract_id=3063227

Kasmir. (2018). Analisis Laporan Keuangan. Cetakan 11. Jakarta: PT Raja Grafindo Persada.

Kemuning, N., \& Juliarsa, G. (2016). Pengaruh Reputasi Auditor dan Ukuran Perusahaan pada Keakuratan dalam Pemberian Opini Going Concern. E-Jurnal Akuntansi, 15(2), 847-861. Retrieved from https://ojs.unud.ac.id/index.php/Akuntansi/article/view/12295

Krissindiastuti, M., \& Rasmini, N. (2016). Faktor-Faktor yang Mempengaruhi Opini Audit Going Concern. E-Jurnal Akuntansi, 14(1), 451-481. Retrieved from https://ojs.unud.ac.id/index.php/Akuntansi/article/view/14624

Kurnia, R., \& Cellica, L. (2016). The Impact of Bankruptcy Prediction, Company's Financial Condition, Previous Year Audit Opinion, Firm Size and Audit Tenure Towards Auditor's Going Concern Opinion. Accounting and Finance Review (AFR), Vol. 1(1) 2016. 51-58, Available at SSRN: https://ssrn.com/abstract=3000214

Lazăr, S. (2016). Determinants of Firm Performance: Evidence from Romanian Listed Companies, Review of Economic and Business Studies, 9 (1), 53-69. https://content.sciendo.com/view/journals/rebs/9/1/article-p53.xml?language=en 
Madhani, P., M. (2016). Firm Size, Corporate Governance and Disclosure Practices: InterRelations. SCMS. Journal of Indian Management, Vol. 13, No. 2, pp. 17-39, 2016, Available at SSRN: https://ssrn.com/abstract=2803036

Muhanguzi, K., B. (2019). An Empirical Test of the Agency Theory in Corporate Governance of SACCOs in Uganda. Available at http://dx.doi.org/10.2139/ssrn.3454396

Rakatenda, G., \& Putra, I. (2016). Opini Audit Going Concern dan Faktor-faktor yang memengaruhinya. E-Jurnal Akuntansi, 16(2), 1347-1375. Retrieved from https://ojs.unud.ac.id/index.php/Akuntansi/article/view/20244

Robu, et all. (2015). The Influence of the Audit Report on the Relevance of Accounting Information Reported by Listed Romanian Companies. Procedia Economics and Finance, Volume 20, Pages 562-570, ISSN 2212-5671, https://doi.org/10.1016/S2212-5671(15)00109-4

Simamora, et all. (2019). The effects of audit client tenure, audit lag, opinion shopping, liquidity ratio, and leverage to the going concern audit opinion. Asian Journal of Accounting Research, Vol. 4 No. 1, 2019 pp. 145-156, https://www.emerald.com/insight/content/doi/10.1108/AJAR-05-2019-0038/full/html

Srimindarti, et all. (2019). Determinants of Going Concern Audit Opinion. Proceedings of the International Conference on Banking, Accounting, Management, and Economics (ICOBAME 2018), volume 86, p 96-99, Issn 2352-5428, https://dx.doi.org/10.2991/icobame-18.2019.21

Sugiyono. (2017). Metode Penelitian Kuantitatif, Kualitatif, dan R\&D. Bandung: CV Alfabeta.

Suryani, S. (2020). Pengaruh Profitabilitas, Ukuran Perusahaan, Debt Default dan Audit Tenure terhadap Opini Audit Going Concern. Jurnal Ilmiah Akuntansi Kesatuan, 8(3), 245 - 252. https://doi.org/10.37641/jiakes.v8i3.346

Utami, M., Sari, M., \& Astika, I. (2017). Kemampuan Prior Opinion Memoderasi Pengaruh Profitabilitas, Leverage, Likuiditas, Pertumbuhan Perusahaan dan Rasio Aktivitas terhadap Opini Audit Going Concern. E-Jurnal Ekonomi Dan Bisnis Universitas Udayana, 28612888. doi:10.24843/EEB.2017.v06.i07.p09

Wardayati, et all. (2017). Impact of Companies' Financial Condition and Growth Toward Acceptance of Going Concern Audit Opinion: Empirical Study at Company Listed in the Jakarta Islamic Index (JII) (July 8, 2017). Accounting and Finance Review (AFR), Vol. 2(3), 1-10, https://papers.ssrn.com/sol3/papers.cfm?abstract_id=3008271

Widoretno, A. (2019). Factors That Influence The Acceptance of Going Concern Audit Opinion on Manufacture Companies. Journal of Economics, Business, and Government Challenges, 2(1), 49-57. https://doi.org/https://doi.org/10.33005/ebgc.v2i1.64

Yuliyani, N., \& Erawati, N. (2017). The Effect of Financial Distress, Profitability, Leverage, and Liquidity on Going Concern Audit Opinion. E-Jurnal Akuntansi, 19(2), 1490-1520. Retrieved from https://ojs.unud.ac.id/index.php/Akuntansi/article/view/28457 